\title{
PENGEMBANGAN ALAT PRAKTIKUM GERAK JATUH BEBAS MENGGUNAKAN SENSOR PHOTOTRANSISTOR UNTUK PEMBELAJARAN FISIKA PADA MATERI GERAK JATUH BEBAS
}

\author{
Sri Maiyena, Marjoni Imamora, Fitri Ningsih \\ Tadris Fisika Fakultas Tarbiyah dan Ilmu Keguruan IAIN Batusangkar \\ Jalan Sudirman No. 137 Lima Kaum Batusangkar \\ Email: srimaiyena@iainbatusangkar.ac.id
}

\begin{abstract}
This study aims to produce free fall practicum tools by utilizing phototransistor sensors to record the travel time of objects that fall from the starting point to the end point. Dealing with free falling equipment (GJB), equipment in schools is generally still very simple that is using a stopwatch. This type of research is a research and development using 4-d model (define, design, develop and disseminate), which is limited to the stage of development to practicalization activities. Data were collected through validation and responses toward administered questionnaires. Data analysis were conducted by analyzing validation sheet and quantitative response questionnaire by finding percentage of each item on the validation sheet. Then the data validation results are analyzed by descriptive technique to describe the quality of the developed product. The result of calibration of free fall practicum by using phototransistor sensor at $40 \mathrm{~cm}, 50$ $\mathrm{cm}$, and $70 \mathrm{~cm}$ distance obtained the average travel time of each object is $0.28 \mathrm{~s}, 0.32 \mathrm{~s}$, and $0.37 \mathrm{~s}$. These results indicate that the practicum tool has been calibrated. Validation of practicum tool is $72,39 \%$ and validation of questionnaire response of practican is $75 \%$, indicating tool categorized valid. Furthermore, this tool is tested in class X.MIA and XI.MIA MAN 3 Payakumbuh which consisted 23 students in the science laboratory of MAN 3 Payakumbuh with the questionnaire response practicality are $87.75 \%$ and $84.41 \%$ respectively which are categorized very practical.
\end{abstract}

Key words: practical tools, phototransistor sensors, free fall motion

\section{PENDAHULUAN}

Fisika adalah ilmu pengetahuan yang mengkaji tentang konsep, fakta, prinsip dan hukum alam yang dibuktikan melalui serangkaian metode ilmiah. Fisika adalah bidang ilmu yang banyak membahas tentang alam dan gejalanya. Mulai dari yang bersifat riil (terlihat secara nyata) hingga yang bersifat abstrak. Fisika tidak hanya mempelajari teori, namun perlu adanya pengamatan terhadap konsep, fakta, maupun prinsip alam. Setelah mempelajari dan memahami konsep dari fisika, maka diharapkan mampu mengaktualisasikan konsep tersebut kedalam kehidupan sehari-hari.

Fisika juga merupakan Ilmu pengetahuan eksperimental yang dibangun berdasarkan eksperimen-ekperimen. Eksperimen yang dilakukan menghasilkan hukum-hukum dan pernyataan-pernyataan tentang konsep fisika itu sendiri. Hukum dan konsep inilah yang dipelajari melalui proses percobaan atau praktikum yang dilaksanakan di laboratorium. Dalam pelaksanaan praktikum dibutuhkan alat pengajaran atau alat praktikum sesuai dengan materi yang akan dipelajari. Alat pengajaran atau alat praktikum memiliki peranan penting dalam pembelajaran yaitu sebagai alat bantu dalam proses belajar mengajar. Menurut Ibrahim(2003) menyatakan bahwa alat pengajaran dapat dikelompokkan dalam dua bagian yaitu yang bersifat umum dan khusus. Alat pengajaran yang bersifat umum yaitu alat pengajaran yang penggunaannya berlaku untuk 
semua mata pelajaran seperti papan tulis, kapur, spidol, dan penggaris, sedangkan alat pengajaran yang bersifat khusus, ialah alat pengajaran yang penggunaannya berlaku khusus untuk mata pelajaran tertentu seperti mikroskop untuk ipa, jangka untuk matematika, dan kuas untuk menggambar.

Berdasarkan pengelompokan di atas, dapat dilihat bahwa alat pengajaran fisika termasuk kepada alat pengajaran yang bersifat khusus. Hal ini dikarenakan alat fisika hanya digunakan khusus untuk materi fisika saja. Alat-alat khusus dalam pembelajaran fisika diantaranya viskositas, bandul, bidang miring, pegas, dan lain sebagainya. Peralatan tersebut di atas umumnya belum mencukupi untuk menerangkan fenomena fisika di SMA/MA sederajat. SMA/MA sederajat juga memerlukan peralatan praktikum untuk materi tumbukan, momen inersia, serta alat khusus untuk gerak jatuh bebas (GJB).

Khusus untuk peralatan gerak jatuh bebas (GJB), peralatan yang ada di sekolah umumnya masih sangat sederhana. Hal ini ditunjukkan dari peralatan untuk menghitung waktu tempuh benda menggunakan stopwatch. Dimana stopwatch on ketika menjatuhkan benda, dan off ketika benda telah sampai di lantai, hanya dengan berbantukan indra penglihatan manusia secara manual. Percobaan seperti ini terkadang menjadi salah satu penyebab kegagalan praktikum, karena mungkin saja dalam penekanan tombol start atau stop pada stopwatch tidak serentak ketika menjatuhkan benda dan ketika benda sampai di lantai. Selain penghitungan waktu tempuh yang masih menggunakan stopwatch, variasi jarak tempuh pun menjadi salah satu faktor kesulitan dalam percobaan ini, karena untuk menentukan jarak tempuh benda praktikan harus mengukur sendiri menggunakan penggaris. Alat praktikum gerak jatuh bebas manual yang ada di MAN 3 Payakumbuh seperti yang ditunjukkan Gambar 1.

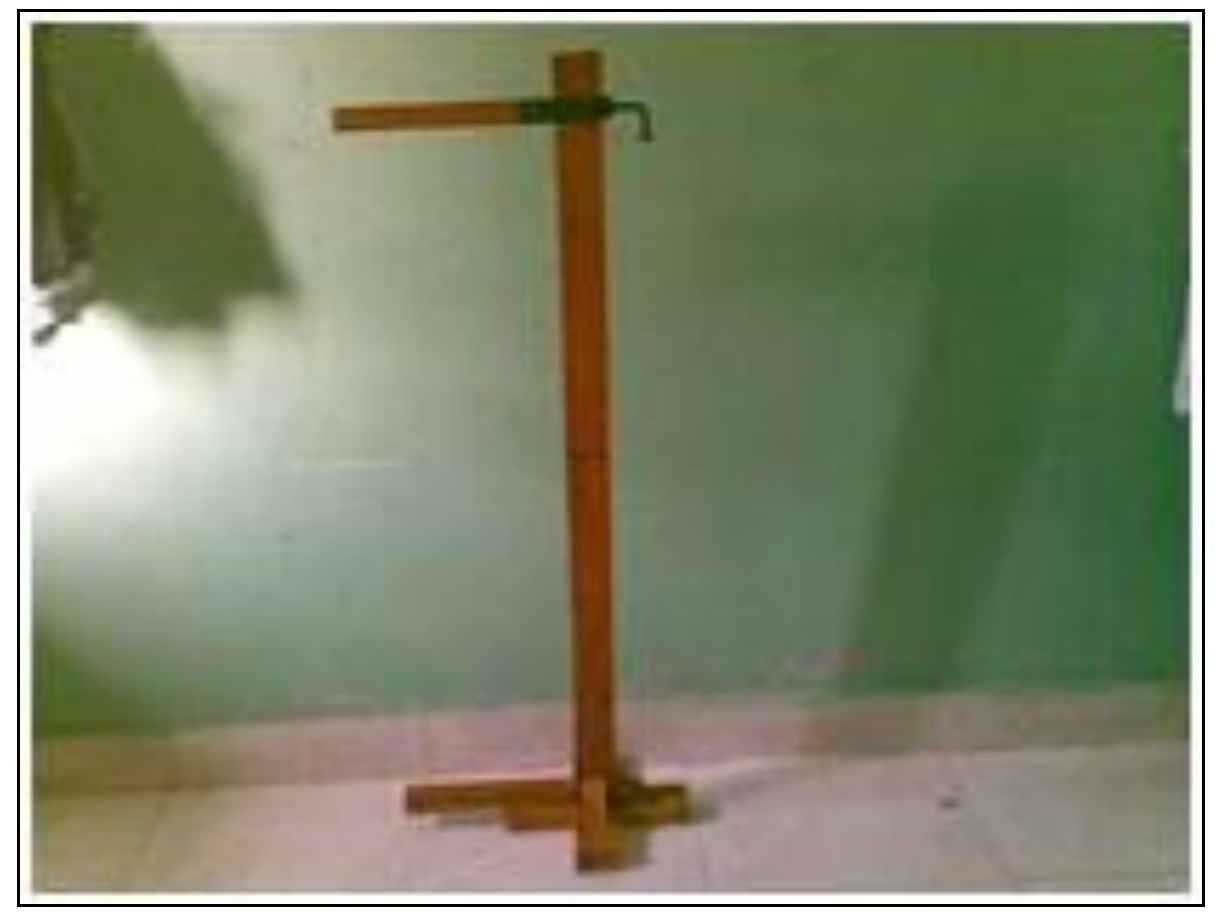

Gambar. 1.1Alat Praktikum GJB manual 
Dewasa ini sudah banyak ditemukan, alat untuk menghitung waktu secara otomatis menggunakan bantuan sensor. Diantaranya, menggunakan sensor LDR, phototransistor, dan photodioda. Sensor adalah suatu peralatan yang berfungsi untuk mendeteksi gejala-gejala atau sinyal-sinyal yang berasal dari perubahan suatu energi seperti energi listrik, energi fisika, energi kimia, energi biologi, energi mekanik dan sebagainya. Sensor juga dikenal sebagai suatu alat yang merubah dari besaran fisika menjadi besaran listrik (Santoso;dkk. 2013). Menurut Fraden di dalam (Pribadi; dkk, 2011), memilih peralatan sensor dan transduser yang tepat dan sesuai dengan sistem yang akan disensor maka perlu diperhatikan persyaratan umum sensor yaitu ditinjau dari linieritas, sensitivitas dan tanggapan waktu.

Beberapa jenis sensor yang digunakan untuk menghitung waktu otomatis adalah seperti sensor LDR, phototransistor, dan photodioda. Penggunaan sensor ini telah digunakan oleh peneliti beberapa sebelumnya, seperti pemanfaatan sensor fototransistor dan LED inframerah dalam mendeteksi kekeruhan air berbasis mikrokontroler At89s51 (Yusfi, 2011) dan pengembangan alat praktikum viskometer dengan memanfaatkan sensor cahaya untuk pembelajaran fisika pada materi fluida (Rahman, 2015) serta Otomasi Blower pada Cerbong Asap Menggunakan Phototransistor (Sanyoto, 2010). Penelitian ini bertujuan untuk menghasilkan alat praktikum gerak jatuh bebas dengan memanfaatkan sensor cahaya yang valid dan praktis dalam pembelajaran fisika.

\section{METODE PENELITIAN}

Penelitian ini merupakan penelitian pengembangan atau research and development (R\&D). Penelitian dirancang dalam 3 tahap yaitu tahap pendefenisian, tahap perancangan dan tahap pengembangan. Pada tahap pendefinisian dilakukan untuk mendapat gambaran kondisi di lingkungan laboratorium Fisika Dasar yang difokuskan pada praktikum gerak jatuh bebas. Melihat adanya keterbatasan pada alat praktikum yang sudah ada, maka dari itu dibuat alat yang dapat memenuhi kekurangan alat yang telah ada, berupa penambahan sensor phototransistor untuk menentukan waktu tempuh benda. Pada tahap ini juga digali atau dipelajari materi tentang gerak jatuh bebas (GJB) khususnya besaranbesaran fisika yang terlibat dalam gerak jatuh bebas seperti gaya gravitasi, ketinggian, waktu dan kecepatan. Dalam hal menentukan waktu dan jarak biasanya ditentukan dengan cara manual, dimana on-off stopwatch dikendalikan langsung oleh praktikan.Untuk mengatasi hal tersebut, penggunaan sensor phototransistor dapat dilakukan. Ketikabenda jatuh pada titik awal, cahaya akan terhalangi dan sensor akan berfungsi sebagai tombol on secara otomatis pada stopwatch. Sedangkan ketika benda sampai pada titik akhir cahaya akan terhalangi dan sensor berfungsi sebagai tombol off pada stopwatch. Sehingga akan tercatat waktu tempuh benda pada tampilan LCD stopwatch.

Pada tahap perancangan, bentuk umum dari alat praktikum yang akan dikembangkan digambarkan terlebih dahulu (gambar 2). Langkah selanjutnya adalah membuat layout dari skema rangkaian sensor cahaya sederhana menggunakan aplikasi droid pcb, selanjutnya adalah menyalin hasil yang telah dibuat ke plastik transparan serta memindahkan layout ke papan printed circuit board (PCB) secara manual dengan menyetrika hasil salinan plastik transpran ke papan PCB. Kemudian, papan PCB tersebut dilarutkan ke dalam larutan feri clorida, dengan tujuan untuk menghilangkan logam yang tidak kena tinta hasil kopian. Langkah selanjutnya adalah memberi lobang pada papan PCB menggunakan bor listrik, agar komponen bisa di pasang, kemudian dilakukan pemasangan komponen rangkaian ke papan PCB dengan memakai timah yang telah dipanaskan solder. Selanjutnya adalah melakukan uji coba/ kalibrasi rangkaian sebelum di letakkan ke dalam sebuah kotak piranti. Langkah terakhir adalah meletakkan rangkaian jadi ke dalam sebuah kotak piranti.

Adapun bahan-bahan yang digunakan untuk proses pembuatan alat praktikum gerak jatuh bebas adalah baterai 9 V, LED (2 buah), 
laser, phototransistor (2 buah), resistor $1 \mathrm{~K} \Omega(2$ buah), relay $9 \mathrm{v}$, diode $1 \mathrm{~N} 40002$, transistor 2N2222, potensio $100 \mathrm{k}$, papan $\mathrm{PCB}$, jumper, kabel, 1 set stopwatch digital, box serta tonggak. Selanjutnya komponen tersebut di atas dirancang dan dirangkai menjadi sebuah alat praktikum gerak jatuh bebas dengan memanfaatkan sensor cahaya (phototransistor).

Variabel yang dihitung pada pengukuran ialah variabel t (waktu). Waktu tempuh dihitung dengan memanfaatkan karekteristik sensor yaitu dengan prinsip perubahan intensitas cahaya yang dibaca oleh sensor cahaya saat benda memotong sinar lampu LED. Perubahan ini menjadi sinyal yang akan dibaca oleh stopwatch yang terpasang dengan rangkaian sensor sebagai waktu tempuh bola sepanjang lintasan d. Sinyal perubahan tegangan yang telah dikondisikan dengan komprator, akan mengaktifkan timer.

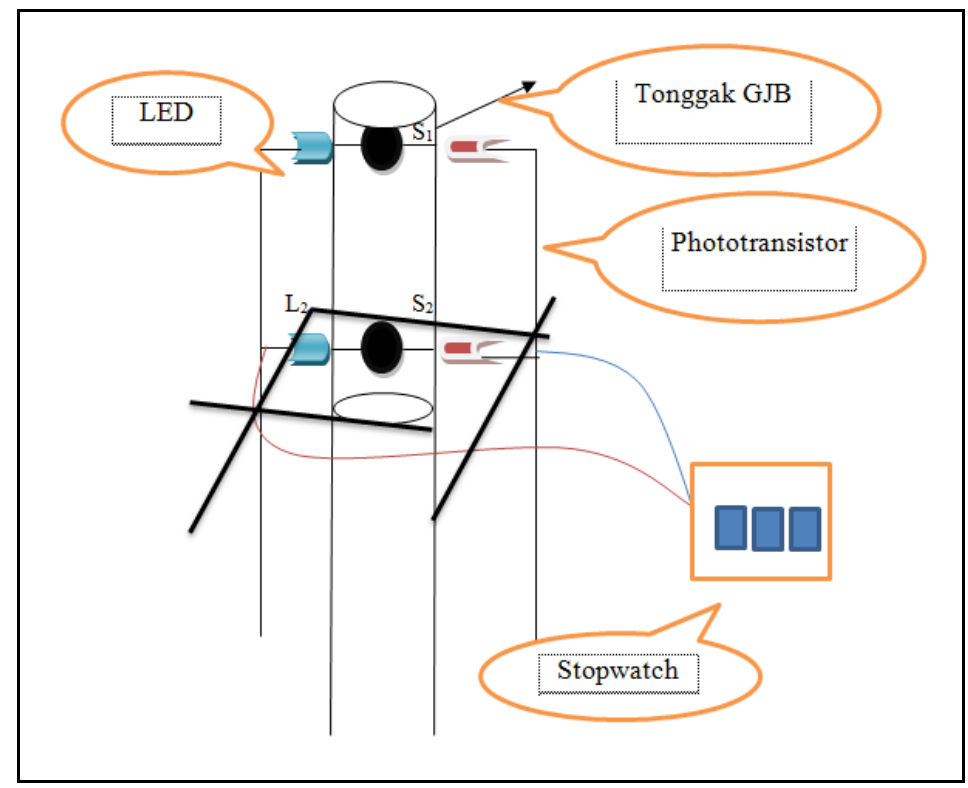

Gambar2. Sketsa Alat Praktikum GJB dengan Memanfaatkan Phototransistor

Setelah tahap perancangan selesai, akan diuji kelayakan alat. Tahap selanjutnya adalah tahap pengembangan. Pada tahap pengembangan ini yang dilakukan adalah uji validitas alat praktikum dan uji praktikalitas alat praktikum. Pelaksanaan validasi dilakukan dengan bantuan pakar. Kegiatan validasi dilakukan dalam bentuk mengisi lembar validasi alat praktikum GJB, hingga diperoleh alat praktikum yang valid dan layak untuk digunakan. Lembar validasi diisi oleh pakar pendidikan fisika dari IAIN Batusangkar. Adapun aspek-aspek yang divalidasi untuk modul penuntun praktikum disajikan pada Tabel 1:

Tabel 1. Validitas Alat Praktikum

\begin{tabular}{llll}
\hline & \multicolumn{1}{c}{ Aspek } & Metode Pengumpulan Data & Instrumen \\
\hline 1 & Tujuan & Validator & Lembar \\
2 & Teknik Pengoperasian & & validasi \\
3 & Ketepatan penggunaan & & \\
4 & Prinsip Kerja & & \\
\hline
\end{tabular}


Setelah divalidasi, selanjutnya dilakukan uji coba terbatas di labor IPA SMA/MA. Uji coba dilakukan untuk melihat keterpakaian alat praktikum yang telah dirancang oleh peneliti. Alat praktikum berbantukan modul penuntun praktikum dikatakan memiliki praktikalisasi yang tinggi apabila bersifat praktis dan mudah digunakan. Adapun komponen yang dipraktikalisasi disajikan pada Tabel 2.

Tabel 2. Praktikalitas Alat Praktikum Gerak Jatuh Bebas

\begin{tabular}{cllc}
\hline No & \multicolumn{1}{c}{ Aspek } & $\begin{array}{c}\text { Metode } \\
\text { Pengumpulan Data }\end{array}$ & \multicolumn{1}{c}{ Instrumen } \\
\hline 1 & $\begin{array}{l}\text { Kemudahan dalam penggunaan alat praktikum } \\
\text { berbantukan modul penuntun praktikum }\end{array}$ & Angket respon & Angket praktikalitas \\
\hline
\end{tabular}

Dari hasil uji validitas yang terkumpul kemudian ditabulasi. Hasil tabulasi tiap tagihan dicari persentase dengan rumus:

$$
P=\frac{\text { Eskor } / \text { item }}{\text { skor maksimal }} \times 100 \% \ldots \ldots \text { (pers 1) }
$$

Berdasarkan hasil persentase, setiap tagihan dikategorikan berdasarkan Tabel 3.

Tabel 3 Kategori Validitas Alat Praktikum (Riduawan,2007, h.89)

\begin{tabular}{cc}
\hline$(\%)$ & Kategori \\
\hline $0-20$ & Tidak Valid \\
$21-40$ & Kurang Valid \\
$41-60$ & Cukup Valid \\
$61-80$ & Valid \\
$81-100$ & Sangat Valid \\
\hline
\end{tabular}

Data hasil tanggapan praktikan melalui angket yang terkumpul, kemudian ditabulasi. Hasil tabulasi tiap tagihan dicari persentasenya dengan persamaan persentase, setiap berdasarkan Tabel 4.
1. Berdasarkan hasil tagihan dikategorikan

Tabel 4. Kategori Praktikalitas (Riduwan,2007, h.92)

\begin{tabular}{cc}
\hline$(\%)$ & Kategori \\
\hline $0-20$ & Tidak Praktis \\
$21-40$ & Kurang Praktis \\
$41-60$ & Cukup Praktis \\
$61-80$ & Praktis \\
$81-100$ & Sangat Praktis \\
\hline
\end{tabular}

\section{HASIL DAN PEMBAHASAN}

\section{Hasil dan Pembahasan Tahap Pendefinisian}

Pada tahap pendefenisian terdiri dari analisis literatur modul penuntun praktikum, alat praktikum yang digunakan, praktikan dan konsep. Berdasarkan hasil analisis perlu dirancang sebuah alat praktikum yang dapat menutupi kelemahan alat yang sebelumnya dengan tidak memerlukan biaya yang sangat mahal. Oleh karena itu peneliti membuat sebuah alat praktikum Gerak Jatuh Bebas 
dengan cara memodifikasi sistem kerja stopwatch yang biasa digunakan untuk praktikum. Penambahan alat memakai saklar otomatis dengan memanfaatkan sensor cahaya (phototransistor) sebagai on-off dari stopwatch, sehingga waktu tempuh benda pada praktikum GJB dapat dideteksi secara akurat.

Dimana, waktu tempuh dihitung dengan memanfaatkan karakterisitik sensor yaitu melalui prinsip perubahan intensitas cahaya yang dibaca oleh sensor saat benda melewati sumber cahaya. Perubahan ini menjadi sinyal yang akan dibaca stopwatch yang terpasang dengan rangkaian sensor sebagai waktu tempuh bola sepanjang lintasan d. Sinyal perubahan tegangan yang telah dikondisikan dengan komprator, akan mengaktifkan timer.

Alat praktikum sangat penting untuk mengkaitkan antara teori dengan hasil praktikum. Ada beberapa hambatan terhadap alat praktikum gerak jatuh bebas yang bersifat manual, sehingga pelaksanaan praktikum tidak berjalan dengan semestinya, jadi kebanyakan praktikan dalam melakukan kegiatan praktikum tidak mengikuti praktikum tersebut dengan serius dan teliti.

Hambatan yang dialami ketika praktikum dengan alat praktikum manual diantaranya adalah kurangnya kesesuian ketika benda dijatuhkan dengan kecepatan praktikan mengaktifkan stopwatch, dan dalam menentukan jarak tempuh pada praktikum gerak jatuh bebas secara manual juga dapat menimbulkan kesalahan pada hasil praktikum, karena jarak tempuh benda dilakukan dengan pengukuran mistar dan penglihatan manusia secara manual.
Jadi, penggunaan alat praktikum secara digital lebih efisien dan praktis serta dapat meminimallisir kesalahan dibandingkan alat praktikum manual. Hasil penelitian ini sesuai pendapat Ambar Tri Utomo, dkk, 2011.

\section{Hasil dan Pembahasan Tahap Perancangan}

Alat praktikum gerak jatuh bebas dengan memanfaatkan sensor phototransistor yang dirancang dalam penelitian ini adalah alat praktikum gerak jatuh bebas pada materi fisika kelas X SMA dengan pokok pembahasan gerak jatuh bebas. Dalam tahap perancangan alat ini dimulai dari mengumpulkan komponenkomponen elektronika dari sebuah rangkaian sensor phototransistor. Setelah semua komponen yang dibutuhkan terkumpul maka dilakukan perancangan terhadap alat.

Langkah pertama yang dilakukan adalah menggambarkan skema rangkaian sensor phototransistor dan yang terpasang pada pcb (Gambar 3.(a) dan (b)). Langkah selanjutnya adalah meletakkan rangkaian jadi kedalam sebuah kotak piranti, yang ditunjukkan pada Gambar 4. Rangkaian yang telah selesai (Gambar 4) dihubungkan dengan stopwatch, dan rangkaian tersebut dimasukkan ke dalam sebuah kotak piranti. Kotak piranti peneliti buat dari kertas karton yang dibentuk menjadi balok dengan ukuran panjang $20 \mathrm{~cm}$, lebar $10 \mathrm{~cm}$, dan tinggi $10 \mathrm{~cm}$. Selanjutnya kotak piranti dilapisi dengan kertas kado, agar tampilan kotak piranti lebih menarik. Kotak piranti yang berisi rangkaian sensor ini diletakkan disamping tonggak dari alat praktikum gerak jatuh bebas (GJB) yang telah dikembangkan. Selanjutnya, alat tersebut dihubungkan dengan sensor cahaya (Gambar 5). 

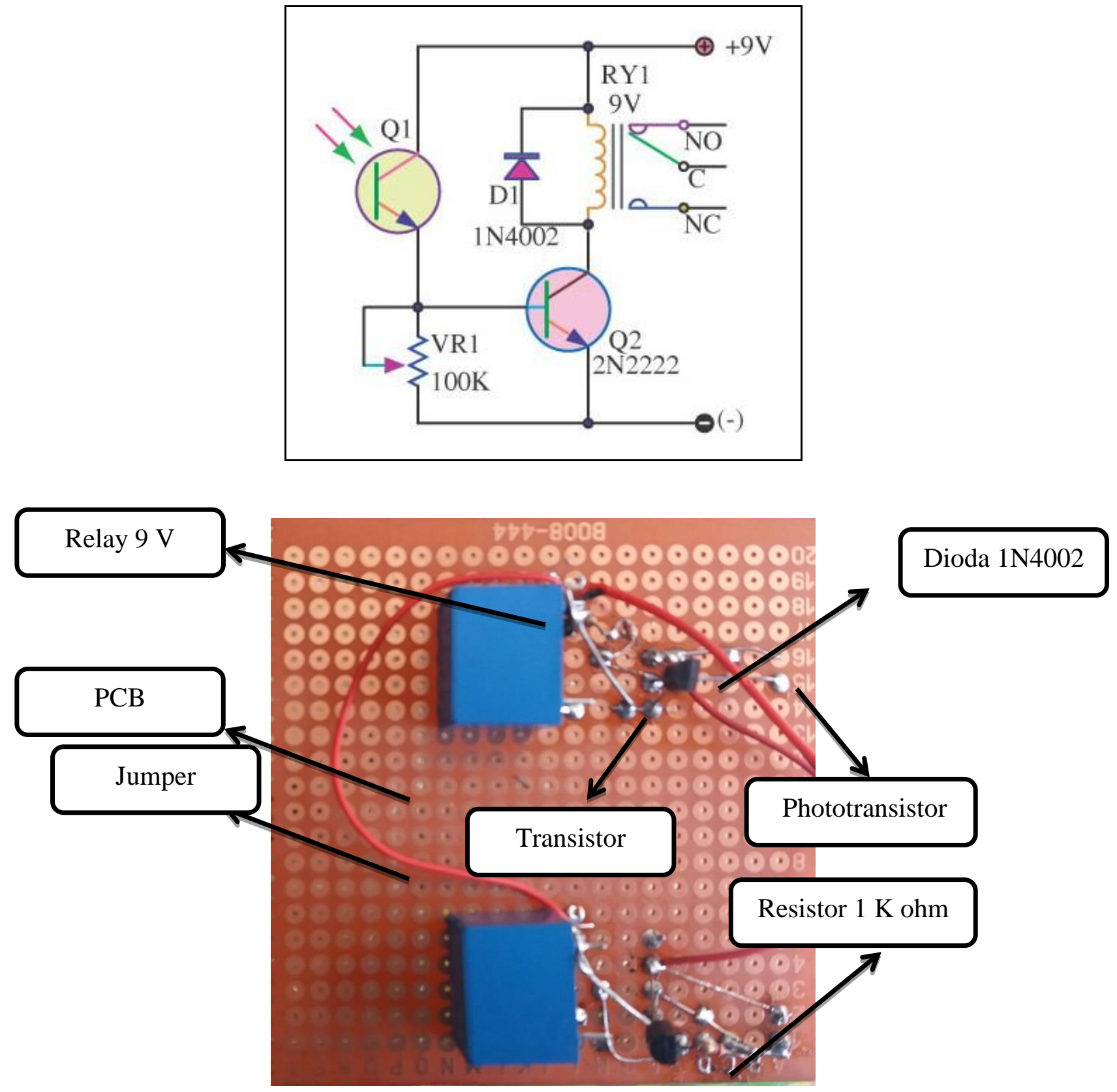

Gambar 3 (a) Skema Rangkaian Sensor Cahaya. (b) Komponen Ragkaian Sensor Cahaya yang Sudah Terpasang di Papan Pcb

Berdasarkan Gambar 5, stopwatch diletakkan di atas kotak piranti yang berisi rangkaian sensor. Setelah itu dihubungkan dengan menggunakan kabel ke dudukan sensor dan sumber cahaya. Dudukan sensor dan sumber cahaya, di buat dari kayu berbentuk lingkaran yang dibagian kiri dalam dan kanan dalam terdapat sensor dan sumber cahaya. Selanjutnya kayu dudukan sensor dan sumber cahaya dibalut menggunakan lakban hitam. Dudukan sensor dan sumber cahaya ini peneliti buat duah buah, yaitu untuk sensor atas dan sensor bawah yang akan dipasang pada tonggak alat praktikum gerak jatuh bebas. jarak antara 
sensor atas dengan sensor bawah dapat disesuaikan dengan jarak tempuh yang akan digunakan dalam menghitung waktu tempuh benda pada praktikum gerak jatuh bebas memanfaatkan sensor phototransistor.

Hasil akhir alat yang sudah dipasangkan pada tonggak GJB untuk praktikum, yang ditunjukkan pada Gambar 6. Berdasarkan Gambar 6, terlihat alat raktikum gerak jatuh bebas yang telah siap untuk digunakan. Tonggak GJB yang peneliti gunakan terbuat dari paralon, dengan diameter 2 inch dan panjang 1,5 meter. Agar tampilan paralon lebih menarik maka peneliti melapisi paralon dengan cat. Salah satu bagian samping paralon peneliti letakkan meteran kain sebagai penunjuk jarak tempuh benda yang akan digunakan. Bagian bawah tonggak GJB terbuat dari kayu yang berbentuk lingkaran dengan ukuran diameter 30 $\mathrm{cm}$. Dudukan sensor yang telah siap dipasang pada bagian atas dan bagian bawah tonggak GJB, pada Gambar 4.4 diatas peneliti menggunakan jarak $70 \mathrm{~cm}$.

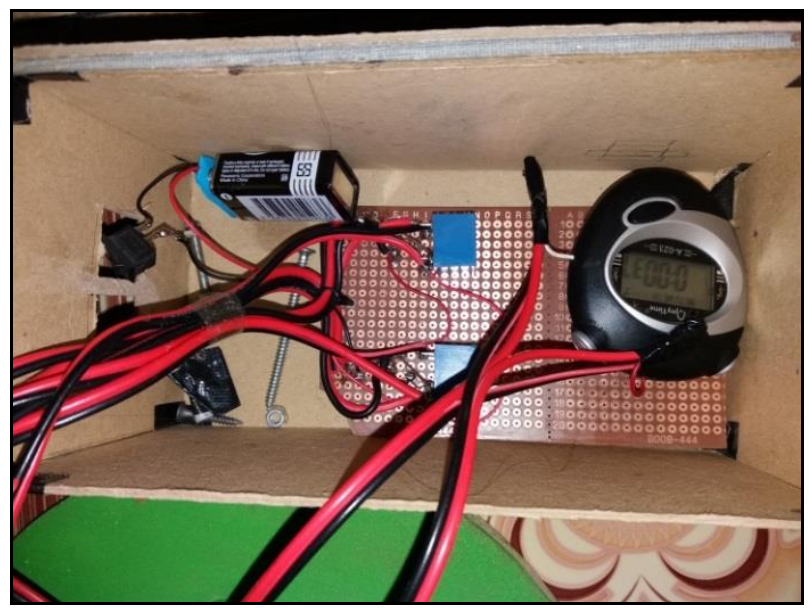

Gambar 4.Rangkaian yang Telah Jadi Dalam Sebuah Box

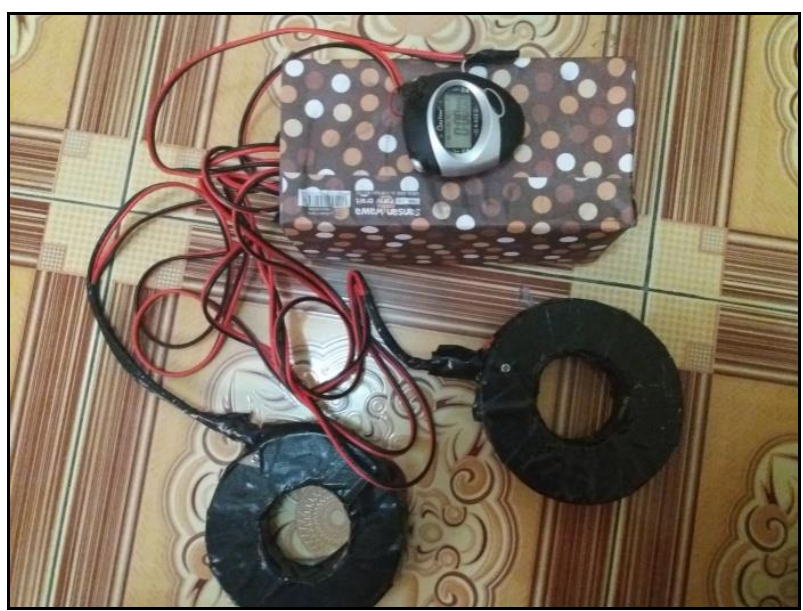

Gambar 5. Hasil Jadi Alat yang Sudah Terhubung dengan Sensor Cahaya 


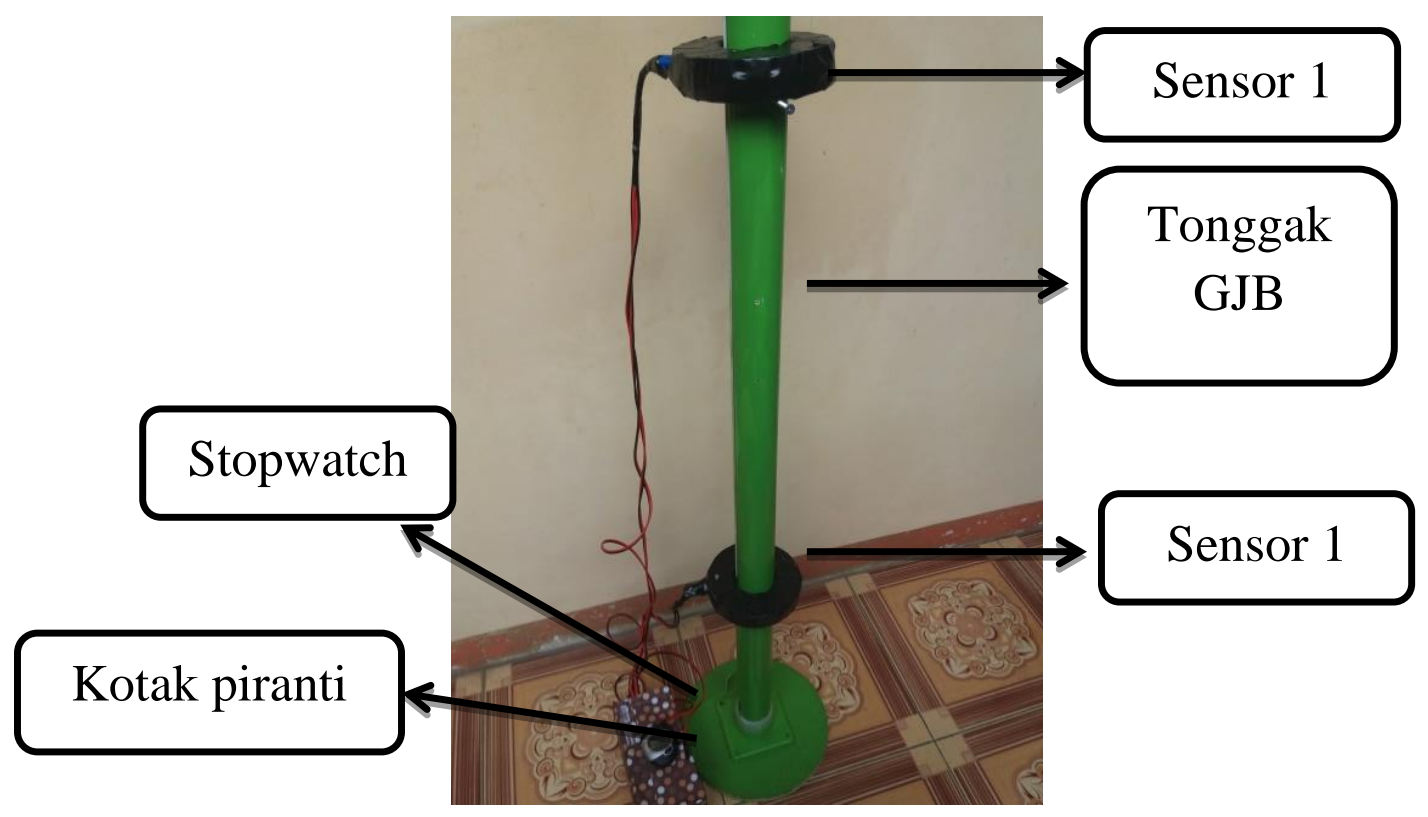

Gambar 6. Alat Gerak Jatuh Bebas yang Sudah Siap untuk dipergunakan

Alat praktikum yang dirancang mengacu kepada pelaksanaan praktikum gerak jatuh bebas pada materi fisika kelas $\mathrm{X}$ MAN 3 Payakumbuh. Alat praktikum gerak jatuh bebas yang peneliti rancang memiliki kelebihan dari alat praktikum gerak jatuh bebas yang ada di laboratorium IPA MAN 3 Payakumbuh. Dimana alat praktikum yang peneliti rancang memanfaatkan sensor phototransistor untuk menghitung waktu tempuh benda secara otomatis. Sensor phototransistor dihubungkan dengan relay yang berfungsi sebagai tombol onoff stopwatch.

Dimana, waktu tempuh dihitung dengan memanfaatkan karakterisitik sensor yaitu dengan prinsip perubahan intensitas cahaya yang dibaca oleh sensor saat benda melewati sumber cahaya. Perubahan ini menjadi sinyal yang akan dibaca stopwatch yang terpasang dengan rangkaian sensor sebagai waktu tempuh bola sepanjang lintasan $d$. Sinyal perubahan tegangan yang telah dikondisikan dengan komparator, akan mengaktifkan timer. Ini sesuai dengan fungsi komparator menurut Piping Supriatna,dkk (2003, h.157) bahwa komparator berfungsi untuk membanding tegangan dari termokopel dengan tegangan referensi.

Sehingga waktu tempuh benda secara otomatis akan terlihat pada display stopwatch yang telah dihubungkan dengan rangkaian sensor.

\section{Hasil dan Pembahasan Tahap Pengembangan}

Setelah alat praktikum siap dirancang dilanjutkan dengan tahap kalibrasi. Dimana dicobakan untuk menghitung waktu tempuh benda pada jarak $40 \mathrm{~cm}, 50 \mathrm{~cm}$ dan $70 \mathrm{~cm}$. Pada percobaan pertama, setelah benda dijatuhkan sensor kurang mendeteksi cahaya sehingga tombol on-off stopwatch tidak berfungsi. Maka dilakukan penyetelan ulang pada sumber cahaya (laser).

Setelah itu, dilanjutkan kalibrasi alat untuk jarak yang sama yaitu $40 \mathrm{~cm}, 50 \mathrm{~cm}$ dan $70 \mathrm{~cm}$, hasilnya sensor bisa mendeteksi pergerakan benda. Dalam melakukan kalibrasi alat, hal pertama yang harus diperhatikan adalah sumber cahaya (laser) telah hidup, sumber daya telah aktif, dan stopwatch telah pada posisi nol. 
Berikut data yang di peroleh dari hasil kalibrasi pada alat praktikum gerak jatuh bebas dengan memanfaatkan sensor phototransistor yang peneliti rancang dengan membanding dari hasil secara teori yang ditunjukkan pada Tabel 5.

Tabel 5. Hasil kalibrasi alat praktikum GJB

\begin{tabular}{rccccc}
\hline NO & Jarak & t praktikum $(\mathrm{s})$ & t praktikum rata-rata $(\mathrm{s})$ & $\mathrm{t}$ teori (s) & \%error \\
\hline 1 & $40 \mathrm{~cm}$ & 0.29 & 0.27 & 0.28 & $3,5 \%$ \\
2 & & 0.28 & & 0.28 & \\
3 & 0.28 & & 0.28 & \\
4 & & 0.27 & & 0.28 & \\
5 & & 0.27 & 0,31 & 0.28 & \\
\hline 6 & $50 \mathrm{~cm}$ & 0,32 & & 0,32 & $3,1 \%$ \\
7 & & 0,30 & & 0,32 & \\
8 & 0,30 & & 0,32 & \\
9 & 0,31 & 0,37 & 0,32 & \\
10 & 0,32 & & 0,32 & 0.37 \\
\hline 11 & 0.37 & & 0.37 & \\
12 & 0.40 & & 0.37 & \\
13 & 0.34 & & 0.37 & \\
14 & & 0.37 & & 0.37 & \\
15 & 0.37 & & & \\
\hline
\end{tabular}

Tabel 5. menunjukkan bahwa kalibrasi alat praktikum gerak jatuh bebas menggunakan sensor phototransistor pada jarak $40 \mathrm{~cm}, 50 \mathrm{~cm}$ dan $70 \mathrm{~cm}$ yang diperoleh melalui eksperimen dengan membandingkan hasil waktu tempuh benda secara praktikum dengan hasil tempuh benda secara teori.

Untuk jarak $40 \mathrm{~cm}$, pada percobaan pertama, waktu tempuh benda yang didapatkan adalah 0.29 sekon, percobaan kedua 0.28 sekon, percobaan ketiga 0.28 sekon, percobaan keempat 0.27 sekon, dan percobaan kelima 0.27 sekon, sedangkan hasil waktu tempuh benda pada jarak $40 \mathrm{~cm}$ secara teori adalah 0.28 sekon. Setelah hasil tempuh secara praktikum dirata-ratakan, didapat hasil waktu tempuh benda secara praktikum adalah 0.27 sekon. Sehingga deviasi error dari kalibrasi alat praktikum gerak jatuh bebas menggunakan sensor phototransistor pada jarak $40 \mathrm{~cm}$ adalah $3,5 \%$. Untuk lebih jelasnya perbandingan waktu tempuh benda pada jarak $40 \mathrm{~cm}$ secara praktikum dengan waktu tempuh benda secara teori dapat dilihat pada gambar 7 . 


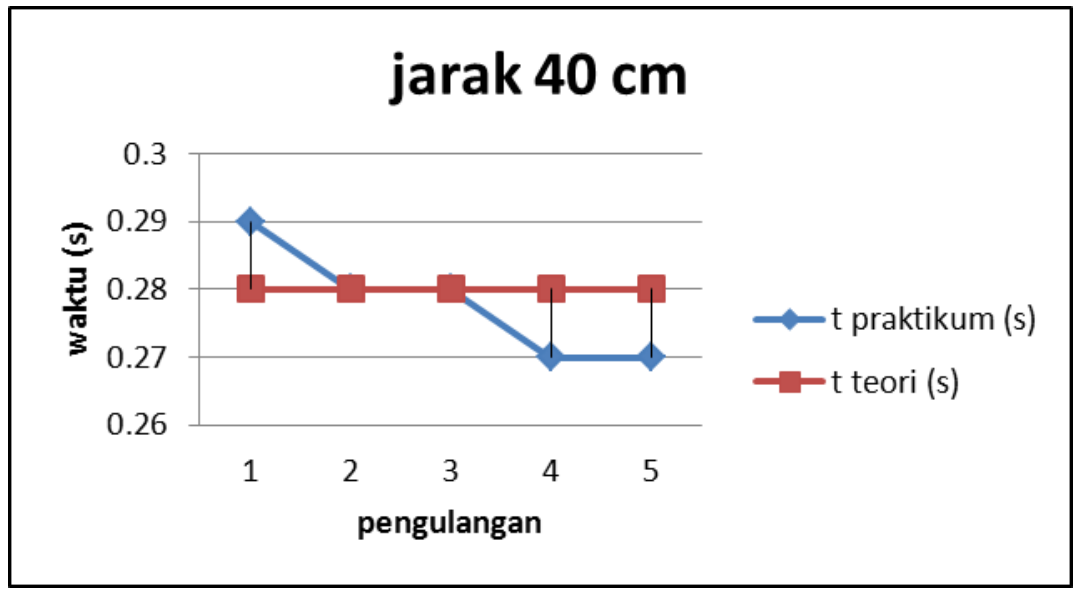

Gambar 7. Perbandingan Waktu Tempuh Hasil Praktikum dengan Hasil Teori

Untuk jarak $50 \mathrm{~cm}$, pada percobaan pertama, waktu tempuh benda yang didapatkan adalah 0.32 sekon, percobaan kedua 0.30 sekon, percobaan ketiga 0.30 sekon, percobaan keempat 0.31 sekon, dan percobaan kelima 0.32 sekon. sedangkan hasil waktu tempuh benda pada jarak $50 \mathrm{~cm}$ secara teori adalah 0.32 sekon. Setelah hasil tempuh secara praktikum dirata-ratakan, didapat hasil waktu tempuh benda secara praktikum adalah 0.31 sekon. Sehingga deviasi error dari kalibrasi alat praktikum gerak jatuh bebas menggunakan sensor phototransistor pada jarak $50 \mathrm{~cm}$ adalah $3,1 \%$. Untuk lebih jelasnya perbandingan waktu tempuh benda pada jarak $50 \mathrm{~cm}$ secara praktikum dengan waktu tempuh benda secara teori dapat dilihat pada Gambar 8.

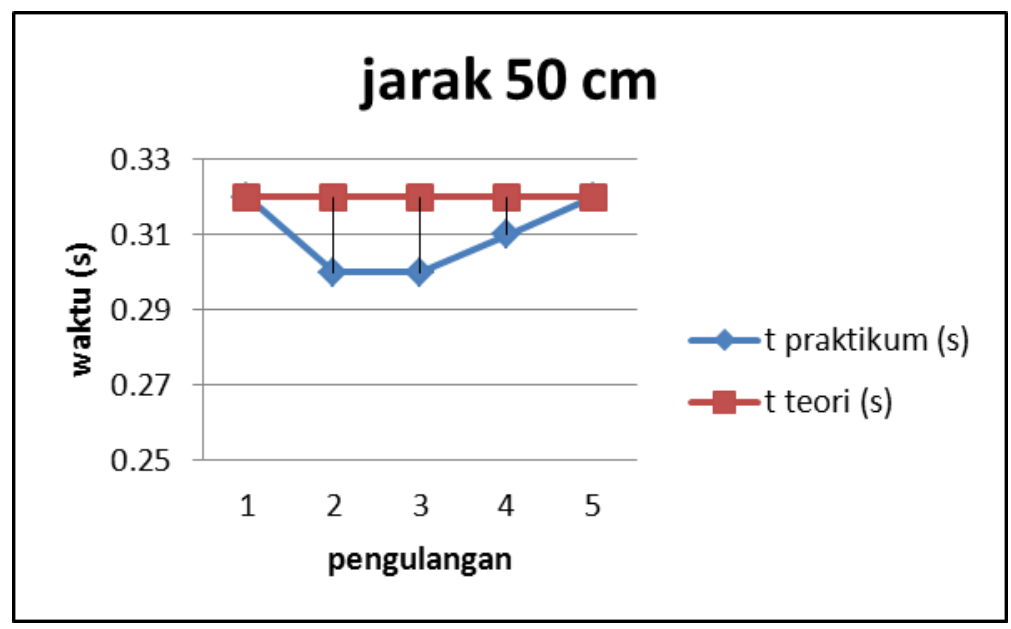

Gambar 8. Perbandingan Waktu Tempuh Hasil Praktikum dengan Hasil Teori

Untuk jarak $70 \mathrm{~cm}$, pada percobaan pertama, waktu tempuh benda yang didapatkan adalah 0.37 sekon, percobaan kedua 0.40 sekon, percobaan ketiga 0.34 sekon, percobaan 
keempat 0.37 sekon, dan percobaan kelima 0.37 sekon. sedangkan hasil waktu tempuh benda pada jarak $70 \mathrm{~cm}$ secara teori adalah 0.37 sekon. Setelah hasil tempuh secara praktikum dirata-ratakan, didapat hasil waktu tempuh benda secara praktikum adalah 0.37 sekon. Sehingga deviasi error dari kalibrasi alat praktikum gerak jatuh bebas menggunakan sensor phototransistor pada jarak $70 \mathrm{~cm}$ adalah $0 \%$. Untuk lebih jelasnya perbandingan waktu tempuh benda pada jarak $70 \mathrm{~cm}$ secara praktikum dengan waktu tempuh benda secara teori dapat dilihat pada gambar 9 .

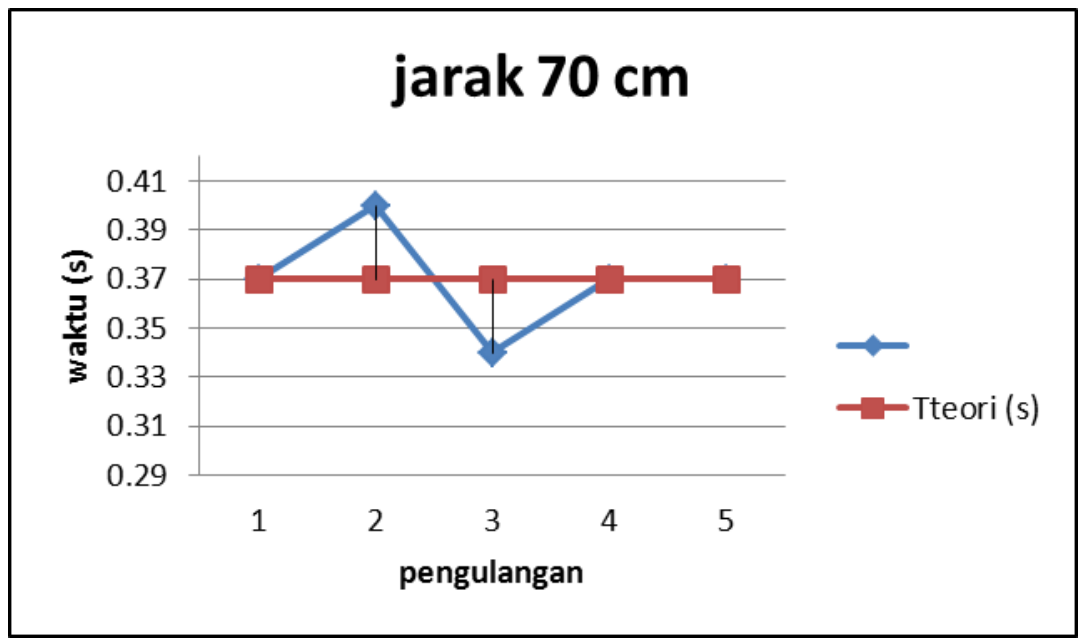

Gambar 9. Perbandingan Waktu Tempuh Hasil Praktikum dengan Hasil Teori

Pada Gambar 7, 8, 9menunjukkan hasil waktu tempuh benda pada praktikum gerak jatuh bebas menggunakan alat praktikum yang peneliti rancang, terlihat bahwa hasil waktu tempuh benda gerak jatuh bebas pada jarak 40 $\mathrm{cm}, 50 \mathrm{~cm}, 70 \mathrm{~cm}$ mendekati hasil waktu tempuh berdasarkan teori.

Alat praktikum gerak jatuh bebas ini dapat dikatakan presisi jika alat ini menunjukkan angka yang sama atau mendekati dengan angka sebelumnya dalam pengukuran berulang yang ditunjukkan pada tabel 5. Pada tabel 5 nilai waktu tempuh benda menunjukkan nilai yang hampir sama pada 5 kali pengukuran berulang. Berdasarkan percobaan gerak jatuh bebas yang telah dilakukan pada jarak $40 \mathrm{~cm}$, didapatkan nilai waktu tempuh benda yaitu 0,39 sekon, 0,28 sekon, 0,28 sekon, 0,27 sekon, 0,27 sekon dan nilai rata-rata dari waktu tempuh benda tersebut adalah 0,27 sekon. Data tersebut menunjukkan bahwa alat praktikum gerak jatuh bebas memiliki nilai presisi yang tepat.
Pada jarak $50 \mathrm{~cm}$, didapatkan nilai waktu tempuh benda yaitu 0,32 sekon, 0,30 sekon, 0,30 sekon, 0,31 sekon, 0,32 sekon dan nilai rata-rata dari waktu tempuh benda tersebut adalah 0,31 sekon. Data tersebut menunjukkan bahwa alat praktikum gerak jatuh bebas memiliki nilai presisi yang tepat. Pada jarak 70 $\mathrm{cm}$, didapatkan nilai waktu tempuh benda yaitu 0,37 sekon, 0,40 sekon, 0,34 sekon, 0,37 sekon, 0,37 sekon dan nilai rata-rata dari waktu tempuh benda tersebut adalah 0,37 sekon. Data tersebut menunjukkan bahwa alat praktikum gerak jatuh bebas memiliki nilai presisi yang tepat.

Pada Tabel 5 berdasarkan percobaan gerak jatuh bebas yang telah dilakukan. Didapatkan nilai waktu tempuh benda pada jarak $40 \mathrm{~cm}$, didapatkan nilai waktu tempuh benda yaitu 0,29 sekon, 0,28 sekon, 0,28 sekon, 0,27 sekon, 0,27 sekon dan nilai rata-rata dari waktu tempuh benda tersebut adalah 0,27 sekon, sedangkan nilai waktu tempuh benda 
pada jarak $40 \mathrm{~cm}$ secara teori adalah 0,28 sekon. Dari nilai waktu tempuh benda tersebut didapatkan ketelitian alat atau accuracy alat yaitu

$$
\% \text { error }=\frac{0,28-0,27}{0,28} \times 100 \%=3.5 \% .
$$

Dari data tersebut alat praktikum gerak jatuh bebas memiliki tingkat accuracy yang tepat.

Untuk jarak $50 \mathrm{~cm}$, didapatkan nilai waktu tempuh benda yaitu 0,32 sekon, 0,30 sekon, 0,30 sekon, 0,31 sekon, 0,32 sekon dan nilai rata-rata dari waktu tempuh benda tersebut adalah 0,31 sekon, sedangkan nilai waktu tempuh benda pada jarak $50 \mathrm{~cm}$ secara teori adalah 0,32 sekon. Dari nilai waktu tempuh benda tersebut didapatkan ketelitian alat atau accuracy alat yaitu

$$
\text { \%error }=\frac{0,32-0,31}{0,32} \times 100 \%=3.1 \% .
$$

Dari data tersebut alat praktikum gerak jatuh bebas memiliki tingkat accuracy yang tepat.

Untuk jarak $70 \mathrm{~cm}$. dimana waktu tempuh benda yang didapatkan berdasarkan hasil percobaan tersebut adalah 0,37 sekon, 0,40 sekon, 0,34 sekon, 0,37 sekon dan 0,37 sekon. Sehingga waktu tempuh rata-rata benda tersebut adalah 0,37 sekon. Dari nilai waktu tempuh benda tersebut didapatkan ketelitian alat atau accuracy alat yaitu

$$
\% \text { error }=\frac{0,37-0,37}{0,37} \times 100 \%=0 \% \text {. }
$$

Dari data tersebut alat praktikum gerak jatuh bebas memiliki tingkat accuracy yang tepat.

Setelah alat praktikum gerak jatuh bebas tersebut memiliki tingkat keakuratan yang tepat, selanjutnya dilakukan validasi. Hasil validasi dari alat praktikum yang dikembangkan adalah $72,39 \%$, dengan kriteria valid.Validator menyarankan untuk merevisi tingkat akurasi dan stabilitas alat.

Untuk melihat praktikalitas alat praktikum gerak jatuh bebas dengan memanfaatkan sensor cahaya, peneliti melakukan uji coba terbatas pada labor IPA MAN 3 Payakumbuh kepada siswa kelas X.MIA dan XI.MIA. Uji coba pengunaan alat praktikum gerak jatuh bebas (GJB) dengan memanfaatkan sensor cahaya dilakukan sebanyak 1 kali pertemuan pada 2 kelas tersebut. Data tentang praktikalitas alat yang telah dikembangkan, dikumpulkan dari lembar angket praktikan. Secara garis besar hasil tanggapan praktikan pada kelas XI.MIA adalah $87,75 \%$ dengan kriteria sangat praktis dan pada kelas X.MIA adalah $84,41 \%$ dengan kriteria sangat praktis.

\section{KESIMPULAN}

1. Hasil kalibrasi alat praktikum gerak jatuh bebas dengan menggunakan sensor phototransistor pada jarak $40 \mathrm{~cm}, 50 \mathrm{~cm}$, dan $70 \mathrm{~cm}$ diperoleh waktu tempuh rata-rata benda masing-masing adalah $0,28 \mathrm{~s}, 0,32 \mathrm{~s}$, dan $0,37 \mathrm{~s}$, hasil ini menunjukkan bahwa alat praktikum sudah terkalibrasi. Validasi alat praktikum $72,39 \%$ dan validasi angket respon praktikalitas $75 \%$, yang menunjukkan alat dikategorikan valid.

2. Hasil uji coba yang dilakukan pada siswa kelas X.MIA dan XI.MIA MAN 3 Payakumbuh yang secara keseluruhan berjumlah 23 orang di laboratorium IPA MAN 3 Payakumbuh dengan hasil angket respon praktikalitas masing-masingnya adalah $87,75 \%$ dan $84,41 \%$ yang dikategorikan sangat praktis.

\section{DAFTAR KEPUSTAKAAN}

Ibrahim R \& Nana SS. 2003. Perencanaan Pengajaran. Jakarta: PT. Renika Cipta.

Pribadi FS dan Sri H. 2011.Rancang Bangun Alat Ukur Ketinggian Lompatan Dengan Sensor Infra Merah. Vol 3 (1)

Rahman AA. 2015. Pengembangan Alat Praktikum Viskometer Dengan Memanfaatkan Sensor Cahaya Untuk Pembelajaran Fisika Pada Materi Fluida. Batusangkar. Sripsi Tidak Diterbitkan.

Riduwan. 2007. Belajar Mudah Penelitian. Jakarta: Alfabeta

Santoso AB, dkk. 2013. Pembuatan Otomasi Pengaturan Api, Pengereman, dan Palang Pintu pada Rel Kereta Api Mainan Berbasis Mikrokontroler. Vol 1 
Maiyena, S., Imamora, M., Ningsih F. 2017. Pengembangan Alat Praktikum Gerak Jatuh Bebas Menggunakan Sensor Phototransistor untuk Pembelajaran Fisika pada Materi Gerak Jatuh Bebas. Journal of Sainstek 9(1): 54-67

Sanyoto NT, dkk. 2010. Otomasi Blower pada Cerbong Asap Menggunakan Phototransistor. 1978-0176

Supriatna P, dkk. 2003. Sistem Kontrol Temperatur untuk Termokopel Chromel Alumel. 1410-0533
Yusfi M, dkk. 2011. Pemanfaatan Sensor Fototransistor Dan Led Inframerah Dalam Pendeteksi Kekeruhan Air Berbasis Mikrokontroler At89s51, 3 (2), 1979-4657 